\title{
Endothelial NADPH oxidases: friends or foes?
}

\author{
Henning Morawietz
}

Received: 22 April 2011/Accepted: 26 April 2011/Published online: 11 May 2011

(C) Springer-Verlag 2011

Reactive oxygen species (ROS) can cause oxidative stress and might promote cardiovascular diseases [22]. On the other hand, increasing evidence supports beneficial effects of ROS as important signaling molecules in the cardiovascular system [5]. NADPH oxidases are main sources of ROS in the vessel wall. Substantial efforts have been made in the 1990s and mainly in the last decade to identify different NADPH oxidase (Nox) isoforms in the vessel wall [3]. The major endothelial Nox isoforms are Nox2 and Nox4 [26]. They might be friends or foes of endothelial function.

Initial studies focussed on the detection and regulation of the classical NADPH oxidase complex containing the catalytic subunit gp91phox (Nox2) in endothelial cells [10, 13, 15, 18, 29]. This complex was first discovered in granulocytes and consists of four subunits, membranebound subunits Nox2 and p22phox and cytosolic subunits p47phox and p67phox. Phosphorylation of cytosolic subunits leads to translocation from the cytosol to the membrane and activation of the complex. Furthermore, its activity requires small $G$ proteins like Rac. Of critical importance is the subunit Nox2 which mediates the electron transfer from NADPH to oxygen, thus causing superoxide anion formation. However, the impact of endothelial-specific overexpression of Nox2 on vascular structure and function in vivo has not been resolved.

In the current issue of Basic Research in Cardiology, Murdoch et al. [27] report that endothelial-specific overexpression of Nox 2 in transgenic mice enhances

H. Morawietz $(\square)$

Division of Vascular Endothelium and Microcirculation,

Department of Medicine III, University of Technology Dresden,

Fetscherstr. 74, 01307 Dresden, Germany

e-mail: henning.morawietz@tu-dresden.de angiotensin II-induced endothelial dysfunction and contributes to vascular remodeling and hypertension. The mice had a twofold increase in endothelial Nox2 expression. This cell-specific increase was compensated under basal conditions with respect to vascular NADPH oxidase activity, endothelial function, and blood pressure. However, the potent vasoconstrictor angiotensin II potentiated vascular ROS formation and endothelial dysfunction in these animals. This is in agreement with previous in vitro studies showing a low expression of Nox2 in healthy endothelial cells, but an induction of Nox 2 in response to pathophysiological stimuli like angiotensin II or oxidized low-density lipoprotein (oxLDL) in human endothelial cells [31, 32, 37]. Exposure to angiotensin II potentiated NADPH oxidase activity in Nox2 transgenic animals compared to wild-type controls. This was accompanied by an impaired endothelial function in response to angiotensin II. These data strongly support a crucial role of endothelial Nox2-generated superoxide anions in endothelial dysfunction. Especially interesting are the data analyzing the blood pressure in Nox 2 transgenic mice in response to low and high doses of angiotensin II. Low angiotensin II dosages had no effect on hemodynamics in wild-type animals, but increased systolic, diastolic, and mean blood pressure in mice overexpressing endothelial Nox2. Higher dosages of angiotensin II raised systolic and mean blood pressures to a similar degree, like in the wild-type, but did not potentiate the response in transgenic Nox 2 animals. Only the diastolic values were increased in these animals compared to wild-type. A potential explanation could be the increasing stimulation of $\mathrm{AT}_{2}$ receptors in response to higher angiotensin II dosages. While the rise in blood pressure is mainly mediated by $\mathrm{AT}_{1}$ receptors, $\mathrm{AT}_{2}$ could act in counterbalancing the effects. Similar dose-dependent findings have been observed after induction of Nox 2 by 

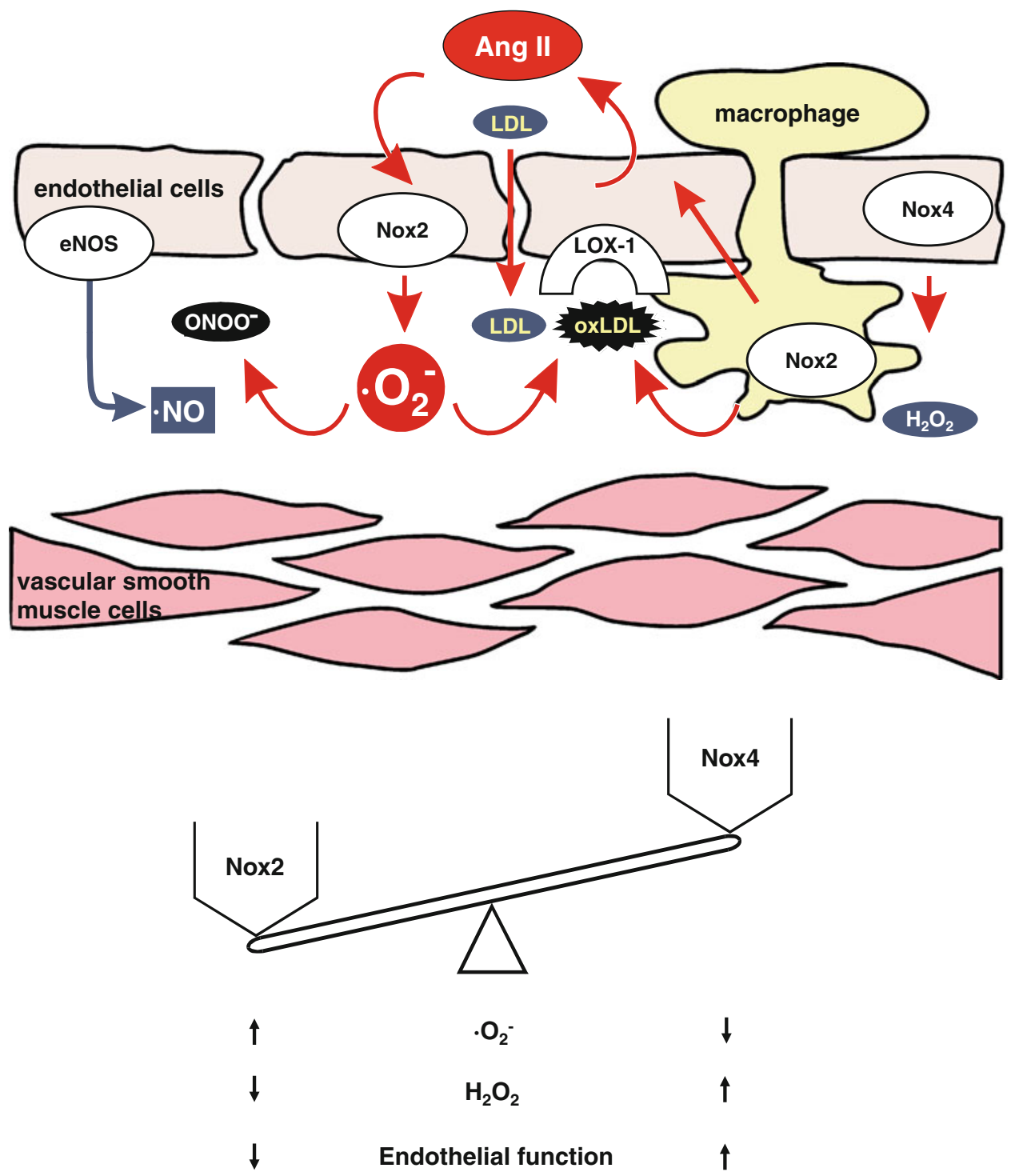

Fig. 1 Nox2 promotes a vicious cycle leading to endothelial dysfunction. The Nox 2 complex releases superoxide anions $\left(\cdot \mathrm{O}_{2}{ }^{-}\right)$. They can inactivate NO, formed by eNOS, thus leading to ONOO. formation and endothelial dysfunction. In addition, low-density

angiotensin II in human endothelial cells [32]. Finally, Murdoch et al. show that this increased activation of ROS in response to angiotensin II affects structural aortic remodeling and activates signaling cascades like the ERK pathway.

An important player in this context could be NO. Endothelial cell in vivo are constantly exposed to hemodynamic forces like shear stress leading to increased eNOS expression and NO formation. While short-term application of shear stress activates an Nox2-containing complex, long-term application of high laminar shear stress causes downregulation of Nox 2 and Nox4 [9, 11]. The flowdependent regulation of both endothelial Nox complexes seems to involve shear stress-dependent release of NO. The lipoprotein (LDL) is oxidized to oxLDL. The oxLDL uptake is preferentially mediated by the LOX-1 receptor in endothelial cells. This vicious cycle can be potentiated by angiotensin II (Ang II). In contrast, the endothelial Nox isoform Nox4 mainly generates $\mathrm{H}_{2} \mathrm{O}_{2}$

crucial role of $\mathrm{NO}$ on endothelial function as shown in the Nox2-overexpressing mice supports this concept.

Superoxide anions can inactivate NO in a very rapid manner leading to formation of the cytotoxic peroxynitrite. Therefore, a well-controlled balance of ROS and NO is necessary to control endothelial function. Another deleterious effect of ROS is the oxidation of LDL. The oxLDL is taken up by endothelial receptors like LOX-1. Because oxLDL itself can further increase Nox2 expression and activity, this could lead to a pro-atherosclerotic vicious cycle (Fig. 1). In later stages of atherosclerosis, infiltrating monocytes/macrophages with a large number of Nox 2 complexes might even further accelerate this vicious cycle. 
Because the basal expression of Nox 2 is low in endothelial cells, its role in endothelial dysfunction has been questioned. The Nox 4 complex is much higher expressed in endothelial cells $[1,12]$. However, the role of Nox4 in the endothelium is not yet resolved. Increasing evidence suggest that the Nox4 complex under normal conditions mainly forms hydrogen peroxide $\left(\mathrm{H}_{2} \mathrm{O}_{2}\right)$ instead of superoxide anions $[33,34]$. Hydrogen peroxide acts in a dosedependent manner as a double-edged sword on the blood pressure and endothelial function. Under physiological conditions low doses of $\mathrm{H}_{2} \mathrm{O}_{2}$ have been described to lower blood pressure. Under certain conditions, $\mathrm{H}_{2} \mathrm{O}_{2}$ is even discussed as EDHF. Murdoch et al. did not observe changes in endothelial Nox4 expression in the mice overexpressing Nox2. However, the concept of a vasoprotective role of Nox4 is also supported by recent data from the group of Ajay Shah in the novel model of mice with transgenic endothelial overexpression of Nox4 [30]. In these mice, the endothelial function is improved due to increased $\mathrm{H}_{2} \mathrm{O}_{2}$ production and $\mathrm{H}_{2} \mathrm{O}_{2}$-induced hyperpolarization. This does not involve altered nitric oxide bioactivity. Nevertheless, endothelial-specific Nox4 mice have a lower blood pressure than wild-type animals [30]. Therefore, the majority of data currently support the model that Nox4 is rather friend, Nox2 rather foe of endothelial function. This view might be wrong under certain pathophysiological conditions. A variety of in vitro studies have shown that high dosages of $\mathrm{H}_{2} \mathrm{O}_{2}$ are deleterious to endothelial cells and induce apoptosis [6]. Therefore, a strong Nox4 expression and activity or a putative "uncoupling" of Nox4 switching its activity back from $\mathrm{H}_{2} \mathrm{O}_{2}$ to superoxide anion formation might tip the balance in the other direction.

Several additional insights came from transgenic models overexpressing different Nox isoforms in specific cell types in the past years. Nox 1 overexpression in vascular smooth muscle cells potentiated angiotensin II-induced hypertension and vascular hypertrophy [7]. Overexpression of p22phox in vascular smooth muscle cells was counterbalanced by increased NO formation and ecSOD expression [23]. Bendell et al. [4] could show a crucial role of endothelial Nox2 in vascular oxidative stress and hemodynamics. Their data strongly support the recent findings of Murdoch et al. [27]. However, angiotensin II-dependent chronic hypertension in mice overexpressing human renin was not affected by the Nox 2 complex [36]. Overexpression of a constitutive active human mutant of Rac1 in vascular smooth muscle cells caused increased superoxide anion and peroxynitrite formation and hypertension [14]. For Nox4, first data from knockout animals do not support a basal effect of Nox4 on blood pressure, but suggest additional roles of Nox4 in heart failure, cardiac angiogenesis, and stroke $[20,21,38]$. In addition, with the help of knockout models, crucial roles for Nox 2 and Nox1 have been shown in renovascular hypertension and angiotensin II-induced hypertension [19, 24]. These data suggest a role of Nox 2 in the development of hypertension.

Inhibition of NADPH oxidase expression and activity might have even important clinical implications. $\mathrm{AT}_{1}$ receptor blockers and statins have been shown to reduce Nox 2 expression in vessels of patients with coronary artery disease $[31,32]$. Both medications can improve endothelial and cardiac function $[8,16,25,28,35]$. This could involve decreased NADPH oxidase activity and improved redox state in the vessel wall [2]. In contrast, most clinical trials with synthetic vitamins have failed to mediate protective effects in cardiovascular diseases and stroke [17]. Potential reasons might include the fact that the vitamin concentration in some trails was too low, or that a single vitamin in comparison to a combination of vitamins $\mathrm{C}$ and $\mathrm{E}$ was not efficient. Furthermore, the typical Western-type diet is supplemented with a variety of antioxidants. Finally, the vitamin concentration might not reach a protective concentration in the target organ after oral uptake. Therefore, a major aim of the vascular redox field is the development of novel antioxidants or isoform-specific Nox inhibitors. They should directly target individual Nox isoforms to reach local antioxidative protection in the affected target tissue.

In conclusion, increasing evidence supports a role of Nox 4 as friend and Nox 2 as foe of endothelial function. In this context, the study of Murdoch et al. is an important proof of concept of the critical role of the deleterious effects of the Nox 2 complex in endothelial dysfunction and hypertension. Nox 2 is back to front.

Acknowledgment This work was supported by the Deutsche Forschungsgemeinschaft (MO 1695/4-1 to H.M.).

Conflict of interest The author declares that he has no conflict of interest.

\section{References}

1. Ago T, Kitazono T, Ooboshi H, Iyama T, Han YH, Takada J, Wakisaka M, Ibayashi S, Utsumi H, Iida M (2004) Nox4 as the major catalytic component of an endothelial NAD(P)H oxidase. Circulation 109:227-233. doi:10.1161/01.CIR.0000105680. 92873.70

2. Antoniades C, Bakogiannis C, Tousoulis D, Reilly S, Zhang MH, Paschalis A, Antonopoulos AS, Demosthenous M, Miliou A, Psarros C, Marinou K, Sfyras N, Economopoulos G, Casadei B, Channon KM, Stefanadis C (2010) Preoperative atorvastatin treatment in $\mathrm{CABG}$ patients rapidly improves vein graft redox state by inhibition of Rac1 and NADPH-oxidase activity. Circulation 122:S66-S73. doi:10.1161/CIRCULATIONAHA.109. 927376

3. Bedard K, Krause KH (2007) The NOX family of ROS-generating NADPH oxidases: physiology and pathophysiology. Physiol Rev 87:245-313. doi:10.1152/physrev.00044.2005 
4. Bendall JK, Rinze R, Adlam D, Tatham AL, de Bono J, Wilson N, Volpi E, Channon KM (2007) Endothelial Nox2 overexpression potentiates vascular oxidative stress and hemodynamic response to angiotensin II: studies in endothelial-targeted Nox2 transgenic mice. Circ Res 100:1016-1025. doi:10.1161/01.RES. $0000263381.83835 .7 \mathrm{~b}$

5. Brandes RP, Weissmann N, Schroder K (2010) NADPH oxidases in cardiovascular disease. Free Radic Biol Med 49:687-706. doi: 10.1016/j.freeradbiomed.2010.04.030

6. Cai H (2005) Hydrogen peroxide regulation of endothelial function: origins, mechanisms, and consequences. Cardiovasc Res 68:26-36. doi:10.1016/j.cardiores.2005.06.021

7. Dikalova A, Clempus R, Lassegue B, Cheng G, McCoy J, Dikalov S, San Martin A, Lyle A, Weber DS, Weiss D, Taylor WR, Schmidt HH, Owens GK, Lambeth JD, Griendling KK (2005) Nox1 overexpression potentiates angiotensin II-induced hypertension and vascular smooth muscle hypertrophy in transgenic mice. Circulation 112:2668-2676. doi:10.1161/CIRCULA TIONAHA.105.538934

8. Diniz GP, Carneiro-Ramos MS, Barreto-Chaves ML (2009) Angiotensin type 1 receptor mediates thyroid hormone-induced cardiomyocyte hypertrophy through the Akt/GSK-3beta/mTOR signaling pathway. Basic Res Cardiol 104:653-667. doi: 10.1007/s00395-009-0043-1

9. Duerrschmidt N, Stielow C, Muller G, Pagano PJ, Morawietz H (2006) NO-mediated regulation of NAD(P)H oxidase by laminar shear stress in human endothelial cells. J Physiol 576:557-567. doi:10.1113/jphysiol.2006.111070

10. Duerrschmidt N, Wippich N, Goettsch W, Broemme HJ, Morawietz $\mathrm{H}$ (2000) Endothelin-1 induces $\mathrm{NAD}(\mathrm{P}) \mathrm{H}$ oxidase in human endothelial cells. Biochem Biophys Res Commun 269:713-717. doi:10.1006/bbrc.2000.2354

11. Goettsch C, Goettsch W, Brux M, Haschke C, Brunssen C, Muller G, Bornstein SR, Duerrschmidt N, Wagner AH, Morawietz $H$ (2011) Arterial flow reduces oxidative stress via an antioxidant response element and Oct-1 binding site within the NADPH oxidase 4 promoter in endothelial cells. Basic Res Cardiol. doi:10.1007/s00395-011-0170-3

12. Goettsch C, Goettsch W, Muller G, Seebach J, Schnittler HJ, Morawietz H (2009) Nox4 overexpression activates reactive oxygen species and p38 MAPK in human endothelial cells. Biochem Biophys Res Commun 380:355-360. doi:10.1016/ j.bbrc.2009.01.107

13. Gorlach A, Brandes RP, Nguyen K, Amidi M, Dehghani F, Busse R (2000) A gp91phox containing NADPH oxidase selectively expressed in endothelial cells is a major source of oxygen radical generation in the arterial wall. Circ Res 87:26-32

14. Hassanain HH, Gregg D, Marcelo ML, Zweier JL, Souza HP, Selvakumar B, Ma Q, Moustafa-Bayoumi M, Binkley PF, Flavahan NA, Morris M, Dong C, Goldschmidt-Clermont PJ (2007) Hypertension caused by transgenic overexpression of Rac1. Antioxid Redox Signal 9:91-100. doi:10.1089/ars.2007.9.91

15. Heusch G, Schulz R (2011) A radical view on the contractile machinery in human heart failure. J Am Coll Cardiol 57:310-312. doi:10.1016/j.jacc.2010.06.057

16. Iliodromitis EK, Andreadou I, Prokovas E, Zoga A, Farmakis D, Fotopoulou T, Ioannidis K, Paraskevaidis IA, Kremastinos DT (2010) Simvastatin in contrast to postconditioning reduces infarct size in hyperlipidemic rabbits: possible role of oxidative/nitrosative stress attenuation. Basic Res Cardiol 105:193-203. doi: 10.1007/s00395-009-0078-3

17. Jialal I, Devaraj S (2003) Antioxidants and atherosclerosis: don't throw out the baby with the bath water. Circulation 107:926-928

18. Jones SA, O'Donnell VB, Wood JD, Broughton JP, Hughes EJ, Jones OT (1996) Expression of phagocyte NADPH oxidase components in human endothelial cells. Am J Physiol 271:H1626-H1634

19. Jung O, Schreiber JG, Geiger H, Pedrazzini T, Busse R, Brandes RP (2004) gp91phox-containing NADPH oxidase mediates endothelial dysfunction in renovascular hypertension. Circulation 109:1795-1801. doi:10.1161/01.CIR.0000124223.00113.A4

20. Kleinschnitz C, Grund H, Wingler K, Armitage ME, Jones E, Mittal M, Barit D, Schwarz T, Geis C, Kraft P, Barthel K, Schuhmann MK, Herrmann AM, Meuth SG, Stoll G, Meurer S, Schrewe A, Becker L, Gailus-Durner V, Fuchs H, Klopstock T, de Angelis MH, Jandeleit-Dahm K, Shah AM, Weissmann N, Schmidt HH (2010) Post-stroke inhibition of induced NADPH oxidase type 4 prevents oxidative stress and neurodegeneration. PLoS Biol 8:e1000479. doi:10.1371/journal.pbio.1000479

21. Kuroda J, Ago T, Matsushima S, Zhai P, Schneider MD, Sadoshima $\mathbf{J}$ (2010) NADPH oxidase 4 (Nox4) is a major source of oxidative stress in the failing heart. Proc Natl Acad Sci USA 107:15565-15570. doi:10.1073/pnas.1002178107

22. Lassegue B, Griendling KK (2010) NADPH oxidases: functions and pathologies in the vasculature. Arterioscler Thromb Vasc Biol 30:653-661. doi:10.1161/ATVBAHA.108.181610

23. Laude K, Cai H, Fink B, Hoch N, Weber DS, McCann L, Kojda G, Fukai T, Schmidt HH, Dikalov S, Ramasamy S, Gamez G, Griendling KK, Harrison DG (2005) Hemodynamic and biochemical adaptations to vascular smooth muscle overexpression of p22phox in mice. Am J Physiol Heart Circ Physiol 288:H7H12. doi:10.1152/ajpheart.00637.2004

24. Matsuno K, Yamada H, Iwata K, Jin D, Katsuyama M, Matsuki M, Takai S, Yamanishi K, Miyazaki M, Matsubara H, YabeNishimura C (2005) Nox1 is involved in angiotensin II-mediated hypertension: a study in Nox1-deficient mice. Circulation 112:2677-2685. doi:10.1161/CIRCULATIONAHA.105.573709

25. Morawietz H, Erbs S, Holtz J, Schubert A, Krekler M, Goettsch W, Kuss O, Adams V, Lenk K, Mohr FW, Schuler G, Hambrecht R (2006) Endothelial protection, AT1 blockade and cholesteroldependent oxidative stress: the EPAS trial. Circulation 114:I296I301. doi:10.1161/CIRCULATIONAHA.105.001313

26. Muller G, Morawietz H (2009) Nitric oxide, NAD(P)H oxidase, and atherosclerosis. Antioxid Redox Signal 11:1711-1731. doi: 10.1089/ARS.2008.2403

27. Murdoch CE, Alom-Ruiz SP, Wang M, Zhang M, Walker S, Yu B, Brewer A, Shah AM (2011) Role of endothelial Nox2 NADPH oxidase in angiotensin II-induced hypertension and vasomotor dysfunction. Basic Res Cardiol. doi:10.1007/s00395-011-0179-7

28. Nagy N, Melchior-Becker A, Fischer JW (2010) Long-term treatment with the AT1-receptor antagonist telmisartan inhibits biglycan accumulation in murine atherosclerosis. Basic Res Cardiol 105:29-38. doi:10.1007/s00395-009-0051-1

29. Park Y, Yang J, Zhang H, Chen X, Zhang C (2011) Effect of PAR2 in regulating TNF-alpha and $\mathrm{NAD}(\mathrm{P}) \mathrm{H}$ oxidase in coronary arterioles in type 2 diabetic mice. Basic Res Cardiol 106:111-123. doi:10.1007/s00395-010-0129-9

30. Ray R, Murdoch CE, Wang M, Santos CX, Zhang M, Alom-Ruiz S, Anilkumar N, Ouattara A, Cave AC, Walker SJ, Grieve DJ, Charles RL, Eaton P, Brewer AC, Shah AM (2011) Endothelial Nox4 NADPH oxidase enhances vasodilatation and reduces blood pressure in vivo. Arterioscler Thromb Vasc Biol. doi: 10.1161/ATVBAHA.110.219238

31. Rueckschloss U, Galle J, Holtz J, Zerkowski HR, Morawietz H (2001) Induction of NAD(P)H oxidase by oxidized low-density lipoprotein in human endothelial cells: antioxidative potential of hydroxymethylglutaryl coenzyme A reductase inhibitor therapy. Circulation 104:1767-1772

32. Rueckschloss U, Quinn MT, Holtz J, Morawietz H (2002) Dosedependent regulation of NAD $(\mathrm{P}) \mathrm{H}$ oxidase expression by angiotensin II in human endothelial cells: protective effect of 
angiotensin II type 1 receptor blockade in patients with coronary artery disease. Arterioscler Thromb Vasc Biol 22:1845-1851

33. Serrander L, Cartier L, Bedard K, Banfi B, Lardy B, Plastre O, Sienkiewicz A, Forro L, Schlegel W, Krause KH (2007) NOX4 activity is determined by mRNA levels and reveals a unique pattern of ROS generation. Biochem J 406:105-114

34. Takac I, Schroder K, Zhang L, Lardy B, Anilkumar N, Lambeth JD, Shah AM, Morel F, Brandes RP (2011) The E-loop is involved in hydrogen peroxide formation by the NADPH oxidase Nox4. J Biol Chem 286:13304-13313. doi:10.1074/jbc.M110. 192138

35. Tiyerili V, Zimmer S, Jung S, Wassmann K, Naehle CP, Lutjohann D, Zimmer A, Nickenig G, Wassmann S (2010) CB1 receptor inhibition leads to decreased vascular AT1 receptor expression, inhibition of oxidative stress and improved endothelial function. Basic Res Cardiol 105:465-477. doi:10.1007/ s00395-010-0090-7
36. Touyz RM, Mercure C, He Y, Javeshghani D, Yao G, Callera GE, Yogi A, Lochard N, Reudelhuber TL (2005) Angiotensin IIdependent chronic hypertension and cardiac hypertrophy are unaffected by gp91phox-containing NADPH oxidase. Hypertension 45:530-537. doi:10.1161/01.HYP.0000158845.49943.5e

37. Zhang H, Schmeisser A, Garlichs CD, Plotze K, Damme U, Mugge A, Daniel WG (1999) Angiotensin II-induced superoxide anion generation in human vascular endothelial cells: role of membrane-bound NADH-/NADPH-oxidases. Cardiovasc Res 44:215-222. doi:S0008-6363(99)00183-2[pii]

38. Zhang M, Brewer AC, Schroder K, Santos CX, Grieve DJ, Wang M, Anilkumar N, Yu B, Dong X, Walker SJ, Brandes RP, Shah AM (2010) NADPH oxidase-4 mediates protection against chronic load-induced stress in mouse hearts by enhancing angiogenesis. Proc Natl Acad Sci USA 107:18121-18126. doi: 10.1073/pnas.1009700107 